\title{
Isolation of pathogenic bacteria from the skin ulcerous symptomatic gourami (Colisa lalia) through 16S rDNA analysis
}

\author{
Mosharrof Hossain
}

Division of Food Science and Aqualife Medicine, Chonnam National University, Chonnam-Yeosu-550-749, Korea.

\begin{abstract}
Aeromonas spp infections are probably the most common bacterial disease diagnosed in cultured warm water fish. In the present study, six strains of Aeromonas spp bacteria were isolated from the gourami (Colisa lalia) by 16S rDNA sequencing analyses that are pathogenic to freshwater fish. Among them, three were under Aeromonas veronii species, two were Aeromonas sp ATCC and one was Aeromonas hydrophila. Colisa lalia usually imported in Korea from the South and South-east Asian countries for recreational purposes. However, they are playing important role as a disease vector or carriers. The infected fish of this study frequently have hemorrhages at the base of the fins or on the skin, and gross ulcerative lesions. Internal signs include, fluid in the abdomen, swollen liver and spleen, and the intestine was distended and fluid-filled. In this study, the utility of $16 \mathrm{~S}$ rDNA sequencing was employed to isolate Aeromonas bacteria from freshwater imported fish are important to environment, veterinary, and clinical purposes.
\end{abstract}

Key word: Bacteria, Colisa lalia, 16S rDNA, Aeromonas

\section{Introduction}

New molecular techniques, such as the $16 \mathrm{~S}$ rDNA polymerase chain reaction (PCR) assay have recently been applied to bacteria screening. This assay relies on the amplification of the gene coding for ribosomal RNA (16S rRNA), which is present in almost all bacteria (Lee et al., 2002; Vernon et al., 2002). This assay has several advantages over traditional microbiological methods. It can detect infections by uncultivable pathogens where routine microbiological techniques have failed to detect the presence of bacteria in the clinical samples. In addition, when combined with DNA sequencing the assay provides a definite identification of the infectious agents. The $16 \mathrm{~S}$ rRNA contains conserved and highly divergent regions. Conserved regions permit the design of broad range PCR primers that will find its target in most bacteria. The genus Aeromonas belonging to the family Aeromonadaceae is found in a diversity of habitats, including soil, water, and are pathogens of warm and cold-blooded animals (Palu et al., 2005). Water environments and food animals are thus important potential sources for the transmission of Aeromonas spp. resulting in human infections (Daskalov, 2006; Kuhn et al., 1997a, b). Aeromonas infections caused by bacteria which are present in the water all of the time. Usually, when fish get sick with an Aeromonas infection, something happened to make them susceptible to bacterial invasion. There are several species of Aeromonas bacteria which can infect fish. The first is Aeromonas salmonicida, which causes a disease called furunculosis in salmon and trout. The two species of Aeromonas which cause disease in warm water fishes are Aeromonas hydrophila and Aeromonas sobria (GcGarey et al., (1991). Aeromonas infections are probably the most common bacterial disease diagnosed in cultured warm water fish. Generally, mortality rates are low and losses may occur over a period of time. In these instances, some factor; usually stress has caused the fish to become more susceptible to the bacteria. Common sources of stress are poor water quality, over crowding, or rough handling. Some strains of Aeromonas spp are more virulent, which means that they possess special properties which enable them to cause more serious disease outbreaks. If these more damaging strains become endemic in a population of fish, it became difficult to introduce new fish into the water body without major losses of newly-stocked fish. Many species have been implicated in fish disease, including $A$. hydrophila, $A$. veronii biovar sobria, $A$. allosaccharophila, and A. salmonicida. Among these, A. hydrophila, A. veronii biovar sobria, A. jandaei, $A$. schubertii and $A$. caviae are most commonly implicated in human intestinal infections (Janda \& Abbott, 1998). These species account for about 85\% of the clinical isolates of this genus and considered major pathogens (Sen \& Rodgers, 2004). Colisa lalia is a most common freshwater species recently imported in Korea for the aquarium fish as for recreation. However, recently lymphocystis disease virus was detected in these imported fish make great concern (Hossain et al., 2008). Thus, in the present study $16 \mathrm{~S}$ rDNA was used to investigation of bacterial pathogen of this imported freshwater gourami Colisa lalia.

\section{Materials and methods}

Sample fish: Skin ulcerative symptomous gourami (Colisa lalia) fish was sampled from the ornamental pet shop, Yeosu, Korea in 2008. These fishes were imported to Korea from South and South-east Asian countries, especially Bangladesh, India, Thailand, Singapore, and Hong Kong (personal communication with pet shops owner). Then fishes were acclimatized in freshwater $10 \mathrm{~L}$ fiber aquarium in the laboratory conditions approximately $20 \pm 2$. Fishes were allowed to feed by pelleted commercial fish meal daily and closely monitored any death or increase ulcerative symptoms. Finally, the fishes were anaesthetized an overdose of MS 222 (Sigma, St. Louis, USA) or dead subsequently organ dissection. 
Bacteria isolation and culture: Bacteria were isolated from different freshly anatomized fish organs like ulcerous lesions, gills, and intestine by a fume sterile loop method. Briefly, the loop heating it red hot and was touch in the respective ulcerative areas or anatomized organs, and then streaking on the pre-prepared $1 \%$ brain heart infusion (BHI) agar plates respectively. The agar plates were incubation at 20 for 24 hours for appropriate colony formation. After the incubation the single colony of each plate was selected for re-isolation to a pure culture.

Genomic DNA isolation: All the bacterial isolates were cultured overnight in $5 \mathrm{ml}$ of brain heart infusion agar medium $\left(1 \%, \mathrm{NaCl}, \mathrm{BHI}\right.$, Eiken) at $20^{\circ} \mathrm{C}$ in a shaking incubator, and then it was centrifuged at $5000 \times g$ for $10 \mathrm{~min}$. The bacterial pellet was washed and resuspended in 0.5 of TE-buffer $(10 \mathrm{mM}$ Tris- $\mathrm{HCl}$, $1 \mathrm{mM}$ EDTA; pH 8.0), and lysed by $10 \%$ sodium dodecyl sulfate (SDS). Then the solution was boiled for $10 \mathrm{~min}$ at 60 , and the cellular debris was discarded following centrifugation at $10,000 \times g$ for $5 \mathrm{~min}$. The total genomic DNA was isolated with phenol-chloroform and precipitated with iced cold $70 \%$ and $100 \%$ ethanol respectively. The resultant pellet was suspension with TE buffer and used as template DNA for PCR amplification.

PCR amplification and sequencing: The presumptive Aeromonas spp were identified on the basis of morphology, gram stain, $\mathrm{KOH}$ test, catalase and oxidase reaction and traditional biochemical methods (Blazevic et al., 1975). The identity of histamine-forming isolates was further confirmed by amplifying and sequencing approximately $1.5 \mathrm{kbp}$ of the $16 \mathrm{~S}$ ribosomal DNA (rDNA) from culture bacteria. Amplification of histamine-forming bacteria was performed using the universal primers fD1 (5'-AGA GTT TGA TCC TGG CTC AG-3') and Rp2 (5'-ACG GCT ACC TTG TTA ACG ACT T-3'). PCR amplification was performed in 20 reaction mixture containing $10 \mathrm{mM}$ Tris $-\mathrm{HCl}(\mathrm{pH}$ $8.3), 50 \mathrm{mM} \mathrm{KCl}, 1.5 \mathrm{mM} \mathrm{MgCl} 2,20 \mathrm{pmol}$ of each primer, a $0.2 \mathrm{mM}$ concentration for each of the four deoxynucleotide triphosphates, $0.5 \mathrm{U}$ of Taq DNA polymerase (Applied Biosystems, Foster City, CA, USA), and template DNA (10 ng). Amplifications were carried out for 35 cycles $\left(94{ }^{\circ} \mathrm{C}\right.$ for $30 \mathrm{~s}, 55^{\circ} \mathrm{C}$ for $30 \mathrm{~s}$, and $72{ }^{\circ} \mathrm{C}$ for $60 \mathrm{~s}$ ) in a GeneAmp PCR 2400 Thermal Cycler (Applied Biosystems, USA) with an initial denaturizing at $94{ }^{\circ} \mathrm{C}$ for $5 \mathrm{~min}$ and a final extension at $72{ }^{\circ} \mathrm{C}$ for $7 \mathrm{~min}$. Amplicons were detected by electrophoresis on a $1.2 \%$ agarose gel, stained with ethidium bromide (Fig.2). Amplicons were cut off from gel and purified using a Wizard $\mathbb{R}$ PCR Purification Kit (Promega, USA) eluted in Tris- $\mathrm{HCl}(10 \mathrm{mM}, \mathrm{pH} 8.5)$ prior to sequencing. The amplified DNA was directly sequenced with the ABI Taq Dye Deoxy Terminator Cycle sequencing kit and ABI Model 377 automated
DNA sequencer (Applied Biosystems, USA). The sequences were analyzed with the BLASTN (NCBI) for identification of bacteria.

\section{Results and Discussion}

In the present study, six strains of bacteria were isolated from the freshwater imported recreational fish gourami (Colisa lalia) in Korea (Table 1).

Table 1. Identification of bacteria using 16S rDNA analysis, using PCR, and BLASTN data sequencing from gourami, Colisa lalia.

\begin{tabular}{c|c|l|c|c}
\hline $\begin{array}{c}\text { Organ } \\
\text { source }\end{array}$ & $\begin{array}{c}\text { Isolates } \\
\text { No. }\end{array}$ & $\begin{array}{c}\text { Highest BLASTN } \\
\text { match with bacteria }\end{array}$ & $\begin{array}{c}\text { Similarity } \\
(\%)\end{array}$ & $\begin{array}{c}\text { Genebank } \\
\text { accession } \\
\text { number }\end{array}$ \\
\hline \multirow{2}{*}{$\begin{array}{c}\text { Jlcerative } \\
\text { lesions }\end{array}$} & 1 & Aeromonas veronii & 100 & EF631963 \\
\cline { 2 - 5 } Gills & 2 & Aeromonas veronii & 100 & EF631962 \\
\cline { 2 - 5 } & 4 & Aeromonas sp. ATCC & 100 & AB235949 \\
\hline \multirow{2}{*}{ Intestine } & 5 & Aeromonas sp.ATCC & 100 & AB235954 \\
\cline { 2 - 5 } & 6 & Aeromonas hydroplila & 100 & EF645799 \\
\hline
\end{tabular}

According to the $16 \mathrm{~S}$ rDNA analyses, all the isolates showed $100 \%$ similarity in the genus Aeromonas. Among them, three were under Aeromonas veronii, one was Aeromonas hydrophila and other two were Aeromonas spp. of American type culture collection (ATCC). There is no single physical or behavioral sign specific for Aeromonas infections. However, infected fish of this study frequently have hemorrhages at the base of the fins or on the skin, and gross ulcerative lesions (Fig.1A). Internal signs include, fluid in the abdomen, swollen liver and spleen, and the intestine was distended and fluid-filled (Fig.1 B).

Anytime an Aeromonas spp infection persists as a chronic problem, therefore, it is important to make an effort to determine if an underlying stress factor is causing the fish to have insufficient immune protection from the bacteria. The genus Aeromonas is a complex group of gram negative ubiquitous bacteria commonly isolated from clinical, environmental, and drinking water samples (Kuhn et al., 1997a). A. veronii has been reported as a food borne pathogen causing infection in fish, food producing animals, and humans (Austin \& Austin, 1993; Isonhood \& Drake, 2002; Janda \& Abbott, 1996). Aeromonas spp. has previously been isolated from ulcerative diseased fish in the Indo-Pakistan region by Iqbal et al. (1998). They found 27\% Aeromonas isolates from fish with ulcerative symptom in Malaysia, Thailand, and Bangladesh belonged to $A$. veronii biovar sobria, and among those 6 of the 11 isolates from Bangladeshi fish. From the above author's description, this paper identified A. veronii, indicating that this Aeromonas species may constitute an important causative agent of epizootic ulcerative disease in Korea. 

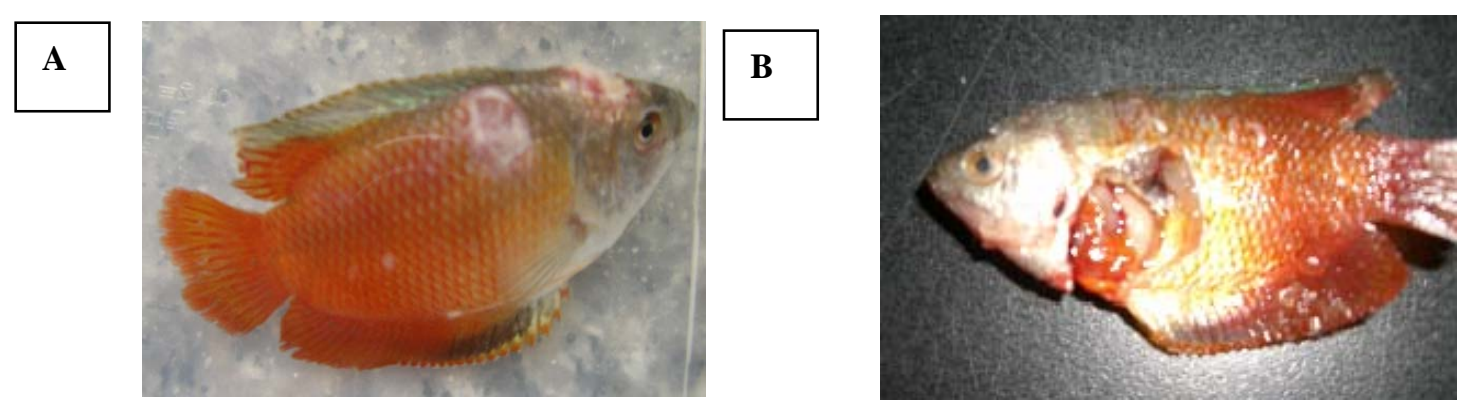

Fig. 1. Skin ulcerous symptomatic gourami,(Colisa lalia). A, live fish (arrows showing ulcerative lesions), B, dissected fish (arrows showing hemorrhage and fluid filled intestine).

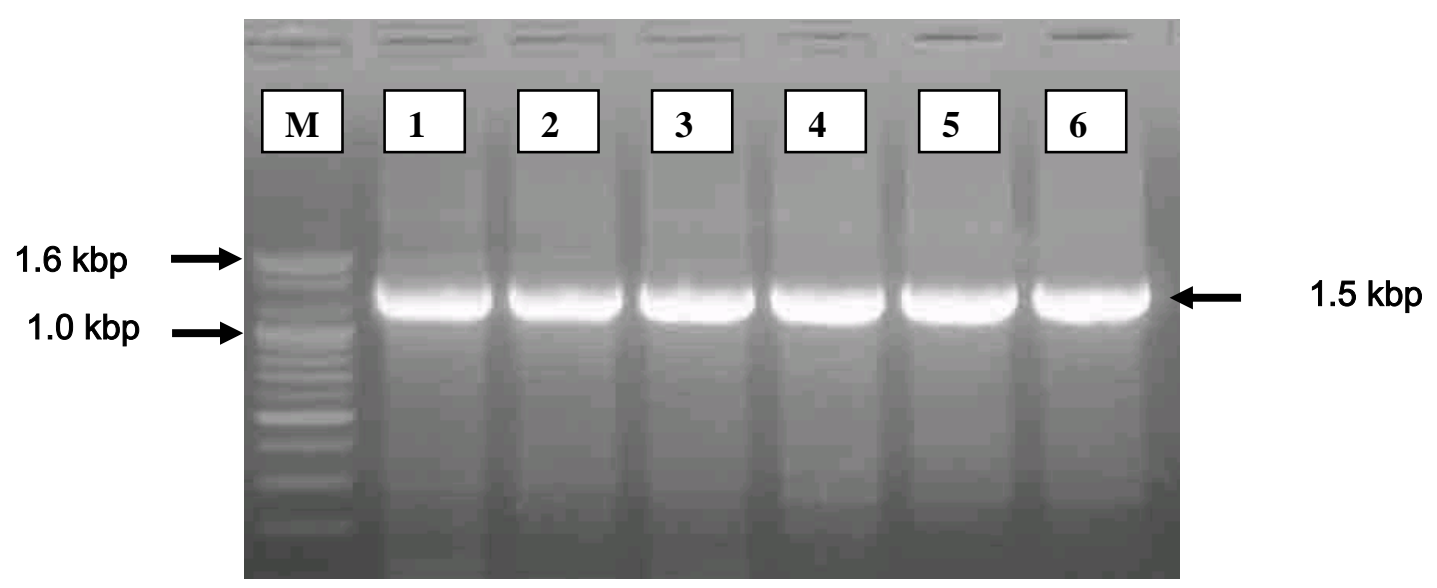

Fig. 2. PCR detection of Aeromonas spp. culture bacterial DNA was used for 16S rDNA analysis. M, molecular marker (100bp DNA ladder, Bioneer, Korea); 1\&2, ulcerative lesions isolates; 3\&4, gill isolates; $5 \& 6$, intestine isolates.(kbp, Kilo base pairs).

Although this gourami is an exotic fish in Korea but the same genus Colisa spp widely found in the freshwater in South Asian country like Bangladesh (Banu \& Bhakta, 1985). A. veronii is also the causative agent of the bacterial hemorrhagic septicemia of fish, which, like A. salmonicida and A. hydrophila, are increasingly considered a major economic problem for the fish-farming industry (Ishiguro et al., 1981; Wiklund \& Dalsgaard, 1998).

GcGarey et al. (1991) described, a common fish disease is epizootic ulcerative symptom characterized by the presence of severe, open dermal ulcers on the head, on the middle of the body, and on the dorsal regions of the fish. Epizootic ulcer disease has been characterized as an epizootic disease of freshwater fish in the IndoPacific region since 1980 (FAO, 1986), and in Bangladesh by Barua et al. (1991). They stated that the disease generally develops with ulcers on the fish bodies, and the fish may die within a week of being infected. This ulcerative symptom observed in the present study in Korea was completely similar like Barua et al. (1991) in Bangladesh. The disease has caused substantial economic loss to fish farmers and the pet and ornamental fisheries sector. Ulcerative syndrome disease is still unknown; however, organisms belonging to the potentially fish-pathogenic genera Aeromonas, Vibrio, Plesiomonas, and Pseudomonas were often isolated from the lesions and blood samples of infected fish (Rahman et al., 2002). Therefore, this study conveys important information to the Colisa lalia ulcerative disease in Korea as well as freshwater gourami of other Asian countries. However, representatives of Aeromonas hydrophila and Aeromonas sobria were recovered most frequently, followed by Vibrio and Plesiomonas spp. (McGarey et al., 1991).

Some bacteria are difficult to identify with phenotypic identification schemes commonly used outside reference laboratories. 16S ribosomal DNA (rDNA)-based identification of bacteria potentially offers a useful alternative when phenotypic characterization methods fail are been used many researcher (Drancourt et al., 2000; Nakatsu et al., 2000; Lee et al., 2002). However, as yet, the usefulness of $16 \mathrm{~S}$ rDNA sequence analysis in the identification of conventionally unidentifiable isolates has not been evaluated with a large collection of isolates. In this study, the utility of $16 \mathrm{~S}$ rDNA sequencing as a means to identify Aeromonas species obtained from freshwater imported fish are important to environment, veterinary, and clinical purposes. The isolated Aeromonas spp are pathogenic itself and also the fish playing an important role as a vector for bacterial disease dispenses. Unlike phenotypic 
identification, which can be modified by the variability of expression of characters, 16S rDNA sequencing provides unambiguous data even for rare isolates, which are reproducible in and between laboratories. These pathogenic Aeromonas spp bacteria isolated from imported gourami Colisa lalia in Korea may be important information to the fish hygiene and quarantine. In conclusion, the new 16S rDNA sequences data analysis pathogenic Aeromonas spp bacterial strains in this study are furtherer needed to check pathogenicity in the other fish species or cellular level respectively.

\section{Acknowledgements}

The Author would like to thank to Professor Myung Joo Oh, Department of Food Science and Aqualife Medicine, Chonnam National University, Korea for conducting the research in his laboratory and possible support for DNA data sequencing and analysis.

\section{References}

Austin, B. \& Austin, D.A. 1993. Bacterial fish pathogens: disease in farmed and wild fish, $2^{\text {nd }}$, ed. Ellis Horwood, Chichester, United Kingdom.

Banu, N. \& Bhakta, N.C. 1985. Observations on the reproductive biology of Colisa fasciata (Bloch and Schneider) (Osphronemidae: Perciformes). J. Asiat. Soc. Bangladesh, 11(2): 63-72.

Barua, G., Banu, A.N.H \& Khan, M.H. 1991. An investigation into the prevalence of fish disease in Bangladesh during 1988-1989. Bangladesh J. Aquacul. 11-13: 27-29.

Blazevic, D.J. \& Ederer, G.M. 1975. Principles of biochemical tests in diagnostic microbiology. John Wiley \& Sons, Inc., New York, N.Y.

Daskalov, H. 2006. The importance of Aeromonas hydrophila in food safety. Food Cont. 6: 474-483.

Drancourt, M., Bollet, C., Carlioz, A., Martelin, R., Gayral, J.P. \& Raoult, D. 2000. 16S ribosomal DNA sequence analysis of a large collection of environmental and clinical unidentifiable bacterial isolates. J. Clin. Microbiol. 38(10):3623-30.

Food \& Agriculture Organisation. 1986. Report of the expert consultation on fish diseases in the Asia-Pacific region. Food and Agriculture Organisation, Bangkok, Thailand.

Hossain, M., Song, J.Y., Kitamura, S.I., Jung, S.J.\& Oh, M.J. 2008. Phylogenetic analysis of lymphocystis disease virus from tropical ornamental fish species based on a major capsid protein gene. J. Fish.Dis. 31(6): 473-479.

Iqbal, M. M., Tajima, K \& Ezura, Y. 1998. Phenotypic identification of motile Aeromonas isolated from fishes with epizootic ulcerative syndrome in Southeast Asian countries. Bull. Fac. Fish. Hokkaido Univ. 49: 131-141.

Ishiguro, E.E. \& Trust, T.J. 1981. Differentiating characteristics of virulent and attenuated strains of Aeromonas salmonicida. Dev. Biol. Stand. 49: 163-168.

Isonhood, J.H. \& Drake, M. 2002. Aeromonas species in foods. J. Food Prot. 65: 557-582.
Janda, J.M. \& Abbott, S.L. 1996. Human pathogens, p.151173. In: The genus Aeromonas Austin B., Attwegg M., Golsin P.J. \& Joseph S. (eds.). John Wiley and Sons, New York, N.Y

Janda, J.M., \& Abbott, S.L. 1998. Evolving concepts regarding the genus Aeromonas: an expanding panorama of species, disease presentations, and unanswered questions. Clin. Infec. Dis. 27: 332-344.

Kühn, I., Albert, M.J., Ansaruzzaman, M., Bhuiyan, N.A., Alabi, S.A., Islam, M.S., Neogi, P.K., Huys, G., Janssen, P., Kersters, K. \& Mollby, R. 1997b. Characterization of Aeromonas spp. isolated from humans with diarrhea, from healthy controls, and from surface water in Bangladesh. J. Clin. Microbiol. 35: 369-373.

Kühn, I., Allestam, G., Huys, G., Janssen, P., Kersters, K., Krovacek, K. \& Stenstrom, T.X. 1997a. Diversity, persistence and virulence of Aeromonas strains isolated from drinking water distribution systems in Sweden. Appl. Environ. Microbiol. 63: 2708-2715

Lee, C., Cho, J.C., Lee, S.H., Lee, D.G. \& Kim, S.J. 2002. Distribution of Aeromonas spp. as identified by $16 \mathrm{~S}$ rDNA restriction fragment length polymorphism analysis in a trout farm. J. Appl. Microbiol. 93: 976-985.

McGarey, D.J., Milanesi, L., Foley, D.P., Reyes, B.J., Frye, L.C. \& Lim, D.V. 1991. The role of motile aeromonads in the fish disease, ulcerative disease syndrome (UDS). Experientia Rev. 47: 441-444.

Nakatsu, C.H., Torsvik, V. \& Øvreås, L. 2000. Soil Community Analysis Using DGGE of 16S rDNA Polymerase Chain Reaction Products. Soil Sci. Soc. America J. 64: 1382-1388

Palu, A.P., Gomes, L.M., Miguel, M.A.L., Balassiano, I.T., Queiroz, M.L.P., Freitas-Almeida, A.C. \& de Oliveira, S.S., 2005. Antimicrobial resistance in food and clinical Aeromonas isolates. Food Microbiol. 23: 504-509.

Rahman, M., Navarro, P.C., Kühn, I., Huys, G., Swings, J. \& Möllby, R. 2002. Identification and Characterization of Pathogenic Aeromonas veronii Biovar Sobria Associated with Epizootic Ulcerative Syndrome in Fish in Bangladesh. Appl. Environ. Microbiol. 68(2): 650655.

Sen, K. \& Rodgers, M. 2004. Distribution of six virulence factors in Aeromonas species isolated from US drinking water utilities: a PCR identification. $J$. App.Microbiol.97: 1077-1086.

Vernon, S.D., Shukla, S., Unger, E.R. \& Reeves, W.C. 2002. Analysis of $16 \mathrm{~S}$ rDNA sequences and circulating cell-free DNA concentration from plasma of a chronic fatigue syndrome and non fatigued subjects.Biomed Central Microbiol. 2: 39

Wiklund, T. \& Dalsgaard, I. 1998. Occurrence and significance of atypical Aeromonas salmonicida in non-salmonicid and salmonid fish species: a review. Dis. Aquat. Org. 32: 49-69.

Manuscript received on 12.07.2008, accepted on 25.08.2008 